\title{
Prevalence of honeybee diseases in Incheon area in 2011
}

\author{
Do-Kyung Ra*, Cheol Jeong, Joo-Ho Lee, Yun-Mi Lee, Kyoung-Ho Kim, \\ Tae-Ho Han, Sung-Mo Lee \\ Incheon Metropolitan City Institute of Health \& Environment, Incheon 404-250, Korea
}

(Received 5 March 2012; revised 27 April 2012; accepted 30 May 2012)

\section{Abstract}

This study investigated the occurrence of honeybee diseases in Incheon area, at the point of great widespread of sacbrood disease in the country. Sixteen resident beekeeping apiaries; 3 native honeybee and 13 European honeybee apiaries were selected for this research. Over 20 adult bees were evenly collected from the most colonies of each apiary three times (March, June, November) within a year. In this work, 13 honeybee diseases including 7 viral diseases, 2 bacterial diseases, 2 fungal diseases, and 2 parasitic diseases were detected by preliminary inspections and PCR. As a result, viral infections were confirmed at 34 among 48 apiaries $(70.8 \%)$ over the entire examination period. Parasitic diseases showed the highest detection rate of $45.8 \%$, which are detected in 44 among 96 cases. In the seasonal prevalence, 30 cases $(15.6 \%)$ of 7 pathogens were detected from 14 apiaries in March, 50 cases (24.0\%) of 9 pathogens and 56 cases $(26.9 \%)$ of 9 pathogens were detected from all apiaries in June and November, respectively. Nosema was shown to be the most prevalent pathogen from March to November, followed by sacbrood virus (SBV) and stonebrood. The spread of SBV infection in Incheon would be underestimated by the increasing of detection rate over the time. Especially, Chinese sacbrood virus was detected from 4 European honybee apiaries, but clinical symptoms were not found. No chalkbrood, acute bee paralysis virus, and chronic bee paralysis virus were detected in this study. The effective therapy and preventive measures should be prepared for beekeeping industry.

Key words : Honeybee diseases, PCR, Nosema, Sacbrood virus

\section{INTRODUCTION}

Honeybees are threatened by various pathogens because of their crowded and warm conditions in social interactions such as mutual grooming and food sharing (Liu et al, 2010). Honeybee diseases can be largely categorized as infectious and parasitic diseases. Infectious diseases are divided into three groups; 6 bacterial diseases, 18 viral diseases, and 2 fungal diseases. Parasitic diseases have been reported 3 internal protozoal diseases and 8 external parasitic diseases (Yoo and Yoon, 2009). Prevalence of viral diseases is estimated to $1.4 \%$ among honeybee diseases, but little has been

\footnotetext{
*Corresponding author: Do-Kyung Ra, Tel. +82-32-440-5650,

Fax.+82-32-440-8863, E-mail. rara9292@korea.kr
}

known about the accurate mechanism causing disease (Yoon, 2001). In general, honeybee viruses are widespread and most of them persist as latent infections. So, it is difficult to diagnose with clinical signs only. However, some diseases not only collapse bee colonies but damage productivity directly. Actually, Chinese sacbrood virus disease emerged in 2009 has caused the collapse of Apis (A.) cerana colonies over $90 \%$ due to infection to larvae and adults in South Korea. Apart from $\mathrm{SBV}$, acariasis, parasitic disease such as nosema, chalkbrood, and foulbrood can cause damage to the domestic beekeeping industry. It is possible to diagnose these parasitic diseases or chalkbrood by their clinical symptoms which make it easier to control the diseases but the early and accurate diagnosis is vital to control other dis- 
eases which show extensively non-specific symptoms.

To date, the diagnosis of honeybee diseases have been largely dependent on experiences and intuitions which cause misdiagnosis in many cases and result in extensive uses of antibiotics, and the emergences of antibiotic resistant bacteria. It is reported that most apiarists virtually tend to self-diagnose when honeybee colonies are collapsed. This fact makes it difficult to apply appropriate treatment and measure because they are unaware of accurate causes of diseases (Chung et al, 2011).

The current situation of the honeybee diseases in Incheon area has never been reported, although national reports about the severity of honeybee diseases and prevalence are available. For this reason, this study intends to diagnose 13 different honeybee diseases and aim to provide the foundation in order to establish appropriate treatments and proper preventive measures against epidemics about the outbreak of honeybee diseases and their distribution in Incheon area.

\section{MATERIALS AND METHODS}

\section{Sample collection}

This study was conducted in 16 apiaries including 3 native honeybee apiaries and 13 European honeybee apiaries among resident beekeeping farms in Incheon in 2011. The herd size of native honeybee apiaries is in the range from 10 colonies to 30 colonies, and that of European honeybee is $200 \sim 300$ colonies. More than 20 adult bees were evenly collected from the most colonies of each apiary, respectively. In order to examine the characteristics of the onset of diseases according to the activity periods of honeybees, samples were collected three times; March (immediately after the wintering), June (major honey flow period), and November (immediately before the wintering).

\section{Extraction of nucleic acid and PCR analysis}

Viral RNA and genomic DNA were extracted from

Table 1. List of primers for honeybee diseases

\begin{tabular}{|c|c|c|c|c|}
\hline Pathogen & Oligonucleotide & Sequence $\left(5^{\prime} \rightarrow 3^{\prime}\right)$ & Product (bp) & Reference \\
\hline \multirow[t]{5}{*}{ Sacbrood virus } & SBV-F & ACCAACCGATTCCTCAGTAG & 487 & Grabensteiner et al, 2007 \\
\hline & SBV-R & CCTTGGAACTCTGCTGTGTA & & \\
\hline & SBV-R 2 & TCTTCGTCCATCCTCATCAC & 258 & Yoo et al, 2007 \\
\hline & CSBV-F & GGATGAAAGGAAATTACCAG & 426 & Liu et al, 2010 \\
\hline & CSBV-R & CCACTAGGTGATCCACACT & & \\
\hline \multirow[t]{2}{*}{ Acute bee paralysis virus } & ABPV-PF & TTATGTGTCCAGAGACTGTATCCA & 901 & Benjeddou et al, 2001 \\
\hline & ABPV-PR & GCTCCTATTGCTCGGTTTTTCGGT & & \\
\hline \multirow[t]{2}{*}{ Chronic bee paralysis virus } & CBPV-F & AGTTGTCATGGTTAACAGGATACGAG & 455 & Ribière et al, 2002 \\
\hline & CBPV-R & TCTAATCTTAGCACGAAAGCCGAG & & \\
\hline \multirow[t]{2}{*}{ Deformed wing virus } & DWV-F & TCATCTTCAACTCGGCTTTCTACG & 479 & Lee et al, 2005 \\
\hline & DWV-R & CGAATCATTTTCACGGGACG & & \\
\hline \multirow[t]{2}{*}{ Black queen cell virus } & BQCV-F & TCGTCAGCTCCCACTACCTTAAAC & 700 & Benjeddou et al, 2001 \\
\hline & BQCV-R & GCAACAAGAAGAAACGTAAACCAC & & \\
\hline \multirow[t]{2}{*}{ Kashmir bee virus } & KBV-F & GATGAACGTCGACCTATTGA & 415 & Choi et al, 2008 \\
\hline & KBV-R & TGTGGGTGGCTATGAGTCA & & \\
\hline \multirow{2}{*}{$\begin{array}{l}\text { Paenibacillus larvae } \\
\text { (American foulbrood) }\end{array}$} & AFB16s NF & GTGTTTCCTTCGGGAGACG & 233 & Lee et al, 2004a \\
\hline & AFB16s NR & CTCTAGGTCGGCTACGCATC & & \\
\hline \multirow{2}{*}{$\begin{array}{l}\text { Mellissococcus pluton } \\
\text { (European foulbrood) }\end{array}$} & EFB-NSF & AAGAGTAACTGTTTTCCTCG & 564 & Ha et al, 2005 \\
\hline & EFB-NSR & ACGCCTTAGAGATAAGGTTT & & \\
\hline \multirow[t]{2}{*}{ Ascosphera apis (Chalkbrood) } & Asco18S-F & GGCTGTAGGGGGGAACCAGGA & 994 & Lee et al, 2004b \\
\hline & Asco18S-R 1 & CGGGTGGTCGTTTCCAGCCTC & & \\
\hline \multirow[t]{2}{*}{ Aspergillus flavus (Stonebrood) } & Asp 18S-F & ATCGGGCGGTGTTTCTATG & 312 & Lee et al, 2004b \\
\hline & Asp 18S-R & ACCGGGCTATTTAAGGGCCG & & \\
\hline \multirow[t]{2}{*}{ Nosema apis } & Nosema-F & CTGCCTGACGTAGACGCTAT & 592 & Yoo et al, 2007 \\
\hline & Nosema-R & CTTCGATCCTCTAGCTTACG & & \\
\hline
\end{tabular}


bee homogenates using DNeasy Blood \& Tissue Kit and RNeasy Mini Kit (Qiagen, Holland). The DNA and RNA were immediately used for PCR. Specific primer pairs were selected to amplify each pathogen (Table 1). Amplifications were carried out in $20 \mu \mathrm{l}$ reaction mixtures employing the Accupower PCR premix or RT-PCR premix (Bioneer, Korea). RT-PCR thermal reactions proceeded with an initial reverse transcription incubation at $50^{\circ} \mathrm{C}$ for $30 \mathrm{~min}$, followed by incubation at $95^{\circ} \mathrm{C}$ for 15 min. This was followed by 40 cycles of denaturation at $94^{\circ} \mathrm{C}$ for $30 \mathrm{sec}$, annealing at $45 \sim 55^{\circ} \mathrm{C}$ for $30 \mathrm{sec}$, and extension at $72^{\circ} \mathrm{C}$ for $1 \mathrm{~min}$. A final extension step was performed at $72^{\circ} \mathrm{C}$ for $10 \mathrm{~min}$. PCR products were electrophoresised in a $1.5 \%$ agarose gel containing 0.05 $\mu \mathrm{l} / \mathrm{ml}$ RedSafe (iNtRON, Korea) and photographed under UV light. Honeybee mites were examined through the preliminary inspection and a microscope.

\section{RESULTS}

\section{The results according to the time of the ex- amination}

30 cases of disease were reported from 14 apiaries in March, 50 cases were reported from all apiaries in June, and 56 cases were reported in all apiaries in November
(Table 2).

\section{The results according to the group of pa- thogens}

Parasitic disease detected in 44 among 96 cases from 33 apiaries showed the highest detection rate of $45.8 \%$, and bacterial disease detected in 19 among 96 cases showed the second highest detection rate of $19.8 \%$ over the entire examination period. Viral disease detected in 57 among 336 cases from 34 apiaries was the third one of $16.8 \%$, and fungal disease detected 16 among 96 cases showed the lowest detection rate of $16.6 \%$ (Table 3 ).

\section{The results according to the type of di- seases}

Seven pathogens and 30 cases including 7 cases of stonebrood (SB), 6 cases of nosema disease, 6 cases of black queen cell virus (BQCV), 5 cases of European foulbrood (EFB), 3 cases of sacbrood virus (SBV), 2 cases of American foulbrood (AFB) and 1 case of acariasis were detected in March. During the honey flow period (flower season), in June, total 9 pathogens and 50 cases including 15 cases of nosema, 9 cases of SBV, 9 cases of AFB, 6 cases of acariasis, 3 cases of deformed wing virus (DWV), 3 cases of stonebrood (SB),

Table 2. Seasonal prevalence of the honeybee diseases

\begin{tabular}{|c|c|c|c|c|c|c|}
\hline \multirow{2}{*}{ Period of honeybees } & \multicolumn{2}{|c|}{ No. of apiary } & \multicolumn{2}{|c|}{ No. of pathogen } & \multicolumn{2}{|c|}{ No. of disease } \\
\hline & Test & Positive (\%) & Test & Positive (\%) & Test & Positive (\%) \\
\hline March (Immediately after wintering) & 16 & $14(87.5)$ & 13 & $7(53.8)$ & 208 & $30(15.6)$ \\
\hline June (Honey flow period) & 16 & $16(100.0)$ & 13 & $9(69.2)$ & 208 & $50(24.0)$ \\
\hline November (Immediately before wintering) & 16 & $16(100.0)$ & 13 & $9(69.2)$ & 208 & $56(26.9)$ \\
\hline Total & 48 & $46(95.8)$ & 39 & $25(69.4)$ & 624 & $136(21.8)$ \\
\hline
\end{tabular}

Table 3. Detection rate according to the group divided by pathogen

\begin{tabular}{|c|c|c|c|c|c|c|}
\hline \multirow{2}{*}{ Group divided by pathogen } & \multicolumn{2}{|c|}{ No. of pathogen } & \multicolumn{2}{|c|}{ No. of apiary } & \multicolumn{2}{|c|}{ No. of disease } \\
\hline & Test & Positive (\%) & Test & Positive (\%) & Test & Positive (\%) \\
\hline Parasite & 2 & $2(100.0)$ & 48 & $33(68.8)$ & 96 & $44(45.8)$ \\
\hline Bacteria & 2 & $2(100.0)$ & 48 & $19(39.6)$ & 96 & $19(19.8)$ \\
\hline Virus & 7 & $5(71.4)$ & 48 & $34(70.8)$ & 336 & $57(16.8)$ \\
\hline Fungi & 2 & $1(50.0)$ & 48 & $16(33.3)$ & 96 & $16(16.6)$ \\
\hline Total & 13 & $10(76.9)$ & 192 & $102(53.1)$ & 624 & $136(31.4)$ \\
\hline
\end{tabular}


Table 4. Frequencies of the various diseases according to the species

\begin{tabular}{|c|c|c|c|c|c|c|c|c|c|c|c|c|c|c|c|c|}
\hline \multirow{2}{*}{ Breed } & \multirow{2}{*}{ Season } & \multicolumn{2}{|c|}{ Parasite } & \multicolumn{2}{|c|}{ Bacteria } & \multicolumn{2}{|c|}{ Fungi } & \multicolumn{7}{|c|}{ Virus } & \multicolumn{2}{|c|}{ Total } \\
\hline & & Mite & Nosema & AFB & EFB & $\mathrm{CB}$ & SB & ABPV & CBPV & DWV & BQCV & KBV & SBV & CSBV & No. & $\%$ \\
\hline \multirow{4}{*}{$\begin{array}{l}\text { Apis cerana } \\
\text { (3 apiaries) }\end{array}$} & March & - & - & - & - & - & 2 & - & - & - & - & - & 3 & - & 5 & 12.8 \\
\hline & June & 1 & 3 & - & - & - & 1 & - & - & - & - & - & 3 & - & 8 & 20.5 \\
\hline & November & - & 1 & - & - & - & 3 & - & - & - & - & - & 3 & - & 7 & 17.9 \\
\hline & Subtotal & 1 & 4 & - & - & - & 6 & - & - & - & - & - & 9 & - & 20 & 17.1 \\
\hline Apis mellifera & March & 1 & 6 & 2 & 5 & - & 5 & - & - & - & 6 & - & - & - & 25 & 14.8 \\
\hline \multirow{3}{*}{ (13 apiaries) } & June & 5 & 12 & 9 & - & - & 2 & - & - & 3 & 1 & 2 & 6 & 2 & 42 & 24.9 \\
\hline & November & 5 & 10 & - & 3 & - & 3 & - & - & 9 & 3 & 5 & 9 & 2 & 49 & 29.0 \\
\hline & Subtotal & 11 & 28 & 11 & 8 & - & 10 & - & - & 12 & 10 & 7 & 15 & 4 & 116 & 22.9 \\
\hline Total & & 12 & 32 & 11 & 8 & - & 16 & - & - & 12 & 10 & 7 & 24 & 4 & 136 & 21.8 \\
\hline
\end{tabular}

AFB: American foulbrood, EFB: European foulbrood, CB: chalkbrood, SB: stonebrood, ABPV: acute bee paralysis virus, CBPV: chronic bee paralysis virus, DWV: deformed wing virus, BQCV: black queen cell virus, KBV: kashmir bee virus, SBV: sacbrood virus, CSBV: Chinese sacbrood virus.

Table 5. Single and mixed infection according to season

\begin{tabular}{lcccccc}
\hline \multirow{2}{*}{ Season } & N.D.* & Single infection & \multicolumn{3}{c}{ Mixed infection } & Total \\
\cline { 4 - 6 } & & & 2 & 3 & 1 & 2 \\
March & 2 & 4 & 7 & 4 & 5 & 16 \\
June & 0 & 1 & 6 & 4 & 8 & 16 \\
November & 0 & 0 & 4 & 9 & 15 & 16 \\
Total & 2 & 5 & 17 & 48 \\
\hline
\end{tabular}

*Not detected.

2 cases of kashmir bee virus (KBV), 2 cases of Chinese sacbrood virus (CSBV), and 1 case of black queen cell virus $(\mathrm{BQCV})$ were identified. Over the period before wintering, total 9 pathogens and 56 cases including 12 cases of SBV, 11 cases of nosema, 9 cases of DWV, 6 cases of SB, 5 cases of KBV, 5 cases of acariasis, 3 cases of EFB, 3 cases of BQCV, and 2 cases of CSBV were detected. Nosema disease was the most prevalent followed by SBV and SB (Table 4). Acute bee paralysis virus (ABPV), chronic bee paralysis virus (CBPV) and chalkbrood $(\mathrm{CB})$ were not identified in this study.

\section{The results according to the species}

The pathogens for 4 different diseases including sacbrood, acariasis, nosema, and stonebrood were identified in three native honeybee apiaries and among these, sacbrood virus were shown in the highest detection rates of $100 \%$ by being identified in all the apiaries. In 13 European honeybee apiaries, all the honeybee disease excluding acute bee paralysis virus, chronic bee paralysis virus and chalkbrood were identified and the prevalence of nosema disease, sacbrood and American foulbrood were $71.8 \%, 38.5 \%$ and $28.2 \%$ respectively over the entire period (Table 4).

\section{Infection aspect according to the number of disease}

Reviewing the aspect of the infections, the single infection was $10.4 \%$ (5 apiaries), double infection was $35.4 \%$ (17 apiaries), and the mixed infection with more than 3 diseases was $50.0 \%$ (Table 5).

\section{DISCUSSION}

Damage by honeybee diseases has been thought to be one of the reasons to reduce the productivity in domestic beekeeping industry. In general, honeybee diseases 
caused by mites, nosema and foulbrood have been reported frequently, but most viral diseases persist as inapparent infections (Ball and Bailey, 1997). Environmental factors and parasite infestations, however, may activate virus infection, which may lead to clinical symptoms (Grabensteiner et al, 2007).

Nosema (N.) apis was first identified by Zender as a bacteria causing nosema disease in honeybee in 1905 and a new species of $N$. ceranae was found among Chinese native honeybee in 1995 (Fries et al, 1996). This pathogen was detected in Spain, Germany and Switzerland, and it has been confirmed to distribute throughout Europe (Higes et al, 2006). It had been also detected in the United States by examining the honeybees in 12 states between 1995 and 2007 (Chen et al, 2008). According to the domestic studies on nosema disease, $56 \%$ of incident rate was reported in 18 apiaries in 2002 (Lee et al, 2003) and Kim et al (2010) reported $73 \%$ of incident rate during the flowering season and $85 \%$ during the season of no blossom of Robinia pseudoacasia L. in 2009. This study examined 16 apiaries in Incheon area in 2011 and the incident rate was 66.7\% in average which ranged between the result of Lee et al (2003) and the result of Kim et al (2010). However, the incident rate during the flowering season was higher than those of non-blossom with the percentage of $93.7 \%$ and $68.8 \%$ respectively in this study showing different from the study result of Kim et al (2010), and this was thought to be stemmed from the fact that nosema disease is the parasitic disease with the characteristics of local epidemic and this study was conducted within Incheon area only.

SBV of A. cerana was first observed in Gangwon Province, Korea in 2009 and subsequently spreaded throughout the rest of Korea. SBV is the a most dangerous virus associated with the collapse of $A$. cerana colonies due to its infection of larvae and adults with high epidemic ability (Ongus et al, 2004). Larvae with sacbrood that failed to pupate, full of ecdysial fluid and rich in SBV beneath their unshed skin, and the body color of infected larvae changed from pearly white to pale yellow.

$76.7 \%$ of native honeybee apiaries were affected by sacbrood virus in 2010. Especially, farms around Jiri
Mountain were severely damaged. In 2011, 126 cases of sacbrood virus infection were reported throughout the country, and it was presumed that occurrences were caused by carrier bees passed the winter. There was not significant cases in Incheon area until 2010 and there was no cases reported among European honeybees until March, but SBV was identified from 6 among 13 subject farms in this study over the activity period and 9 among 13 subject farms in November suggesting that sacbrood virus was spreading among European honeybees over the time. CSBV was not identified from native honeybees at all in this study, but it was identified from 4 European honeybee apraries in the sample of June and November totally. However, these CSBV infections were supposed to be inapparent infections because there were no clinical symptoms in the all positive apiaries. The infection rate of SBV and CSBV was $50.0 \%$ which was significantly higher than the previous report by Choi et al (2008) with the figure of 5.6\% and the report by Yoo and Yoon (2009) with the figure of $17.6 \%$ and this was thought to be resulted from the proliferation of virus secondary epidemics in 2010 2011 .

Foulbrood can be classified into American foulbrood and European foulbrood according to pathogens and it is known that the symptoms of American foulbrood are severer. Foulbrood was first occurred in the middle land of South Korea in 1950's which almost completely destroyed domestic apiculture and it is still occasionally reported in some areas with less severe degree (Yoon, 2002). Foulbrood showed $39.6 \%$ of detection rate in this study and the infection rate was $56.3 \%$ during the activity period by being identified in 9 among 16 farms which was similar to the reported figure of $58.8 \%$ by Yoo and Yoon (2009) and this was thought to be caused by early rainy season.

Chalkbrood caused by Aspergillus spp. and Aspergillus flavus is the most commonly identified pathogen. Stonebrood is frequently confused with chalkbrood as the characteristics resemble each other. Pathogenic spores germinate and infest the gut of the larvae resulting in mummification of the brood of bee appearing chalky (Lee et al, 2004b). Despite the fact that it has been perceived as minor honeybee disease comparing foulbrood or parasitic diseases, the infection rate of stonebrood in 
this study was $33.3 \%$ and it seemed to be more problematic in the native honeybee apiaries.

Deformed wing virus, black queen cell virus and kashmir bee virus were identified and their detection rates were $25.0 \%, 20.8 \%$ and $14.6 \%$ respectively. These values appeared to be lower comparing the results of $33 \%, 35.6 \%$ and $27.9 \%$ by Yoo and Yoon (2009) and $66.67 \%, 33.3 \%$ and $11.11 \%$ by Choi et al (2008). Especially, deformed wing virus which is known to be occurred by Varroa mites, its detection rates have been reported depending on the area and Incheon area were shown in lower infection rate compared to the other areas. Overall characteristics of infection according to the farms showed that $10.4 \%$ were suffered from a disease, $35.4 \%$ were suffered from 2 different diseases, $22.9 \%$ of them were suffered from 3 different diseases and $27.1 \%$ of them were suffered from more than 4 different diseases. These results suggested that more than $50 \%$ of subjects became infected from more than 3 different diseases similar to the study results by Yoo and Yoon (2009).

The current situation of honeybee diseases in Incheon area was firstly confirmed in this study and it showed that a great number of apiaries were exposed to honeybee diseases. It was also confirmed that viral diseases were the case of multi-infection caused by more than 2 pathogens although they were latent infection without clear clinical symptoms. Continuous monitoring of the diseases is necessary for the correct diagnosis of the diseases which changes diversely during the different active periods and for the establishment of the prompt control measures. The accurate diagnosis of honeybee diseases would only facilitate to settle appropriate control measures contributing to the productivity and the quality improvements of apiculture products.

\section{REFERENCES}

Ball BV, Bailey L. 1997. Viruses. pp. 11-31. 1st ed. In: Morse RA, Flottum K(ed.). Honey bee pests predators and diseases. AI Root Co., Medina.

Benjeddou M, Leat N, Allsopp M, Davision S. 2001. Detection of acute bee paralysis virus and black queen cell virus from honeybees by reverse transcriptase PCR. Appl En- viron Microbiol 67: 2384-2387.

Chen YP, Evans JD, Smith IB, Pettis JS. 2008. Nosema cerana is a long present and side spread microsporidian infection of the European honeybee (Apis mellifera) in the United States. J Invert Pathol 97: 186-188.

Choi YS, Lee ML, Lee MY, Lee KG. 2008. Occurrence of seven honeybee viruses and research of disease occurrence in Korean apiaries. Korean J Apiculture 23: 153-159.

Chung NK, Hwang IS, Park SG, Jeong GU. 2011. Survey of beekeeper's consciousness for diagnosis and treatment on disease of honey-bees. Korean J Vet Serv 34: 81-86.

Fries IM, Feng F, da Silva AJ, Slemenda SB, Pieniazek NJ. 1996. Nosema ceranae n. sp. (Microsporidia, Nosematidae), morphological and molecular characterization of a microsporidian parasite of the Asian honey bee Apis cerana (Hymenoptera, Apidae). Eur J Prositol 32: 356-365.

Grabensteiner E, Bakonyi T, Ritter W, Pechhacker H, Nowotny N. 2007. Development of a multiplex RT-PCR for the simultaneous detection of three viruses of the honeybee (Apis mellifera L.): Acute bee paralysis virus, Black queen cell virus and Sacbrood virus. J Invertebr Pathol 94: 222-225.

Ha JS, Lee HM, Kim DS, Lim YK, Yoon BS. 2005. A PCR detection method of Melossococcus pluton for rapid identification of European Foulbrood. Korean J Apiculture 20: 9-18.

Higes M, Martin R, Meana A. 2006. Nosema cerana, a new microsporidian parasite in honeybees in Europe. J Invert Patho 92: 93-95.

Kim NS, Lee MY, Hong IP, Choi YS, Kim HK, Lee ML, Lee KG. 2010. Prevalence of honeybee (Apis mellifera) nosema disease by season in Korea. Korean J Apiculture 25: 25-29.

Lee DB, Yang OS, Han SH, Lim YK, Yoon BS. 2004a. Rapid detection of Paenibacillus larvae larvae caused American foulbood using real-time PCR. Korean J Apiculture 19: 97-108.

Lee HM, Ha JS, Jo YH, Nam SH, Yoon BS. 2004b. PCR detection method of Ascosphera apis, Aspergillus flavus for rapid identification of fungal disease in honeybee. Korean J Apiculture 19: 139-148.

Lee HM, Lee DB, Han SH, Lee ML, Lim YK, Yoon BS. 2005. Identification of deformed wing virus from the honeybee in Korea and establishment of PCR detection method. Korean J Apiculture 20: 85-94.

Lee ML, Choi JY, Lee MY, Kim YS. 2003. Infection level of honeybee nosema disease in Korea. Korean J Apiculture 18: 151-154.

Liu X, Zhang Y, Yan X, Han R. 2010. Prevention of Chinese sacbrood virus infection in Apis cerana using RNA interference. Curr Microbiol 61: 422-428.

Ongus JR, Peters D, Bonmatin JM, Benqsch E, Vlak JM, van Oers MM. 2004. Complete sequence of a picorna-like virus of the genus Iflavirus replicating in the mite Varroa destructor. J Gen Virol 85: 3747-3755. 
Ribière M, Triboulot $\mathrm{C}$, Mathieu L, Aurières $\mathrm{C}$, Faucon JP, Pépin M. 2002. Molecular diagnosis of chronic bee paralysis virus infection. Apidologie 33: 339-351.

Yoo MS, Lee DW, Kim LW, Kim DS, Kwan SH, Lim YG, Yoon BS. 2007. Identification of black queen cell virus from the honeybee in Korea. Korean J Apiculture 22: 43-52.

Yoo MS, Yoon BS. 2009. Incidence of honeybee disease in
Korea 2009. Korean J Apiculture 24: 273-278.

Yoon BS. 2001. Occurrence and preventive situation for effective prevention and control of honeybee diseases. pp. 1-30. The Korea beekeeping bulletin.

Yoon BS. 2002. Honeybee disease and control. pp. 9-11. The Korea beekeeping bulletin. 